\title{
Strange acknowledgements of several kinds
}

We have numerous people to thank, not least of all each other, for persevering during the (sometimes painful) process of translating our passions into a book. Those people include Pamela Bruder-Freeman, Dumitru Chitoran, Gavin Fairbairn, Nicola Groves, Sneja Gunew, Jalna Hanmer, Amanda Hawley, Ian Hunter-Smart, Patricia Johanson, Simon Lee and his ethical and 'running stream' visions, Myra Macdonald, Cam McDonald, Michael Posluns, Sheila Scraton, Arle Sklar-Weinstein (whose insights and explorations inspired the material on art and craft in Chapter 6), Willie Thompson, Paul Tyrer (without whom the manuscript might still be in our computer), Dave Webb, Angus Wells, Bud Whiteye and everyone whose e-mails we failed to respond to on account of being too busy with writing. The editorial staff at Edinburgh University Press are - to a man and woman - kind, attentive, efficient and insightful; we thank Sarah Edwards, James Dale, Eddie Clark, and Nicola Wood, whose sharp eye and quick wit made the copy-editing process almost enjoyable.

There are those to whom we wish to pay special tribute. On Valerie's part, they include the one with boundless energy and a gift for turning fury into prose, lover of olives and humans (probably in reverse order); Pete, centre of the universe and not at all (as an impertinent writer once suggested) a 'myth'; the magnificent MMZ and her parents, Peggy Jane and David and uncle Daniel; Rachel, Bill and Susan - ethical judge and champion punster; the rest of the family (you know who you are; we know where you live); the life-saving support of Dr Shahid Junejo; the early inspiration of Jenny Wells Vincent and the incomparable Paul Robeson; the music and spirit of Evelyn Pittman in the early Oklahoma days.

On Simone's part, they are D, for ensuring that my passions came before mundane necessities and for allowing me to hog the limelight; the night owl, for being the sort of mentor who sends e-mails at three in the morning; Rebecca Sutcliffe - student extraordinaire, who deserves much of the credit for the material on asylum seekers in Chapter 1; Pete, for the olives and a space to think out loud - in that order!; Ngahuia 
Te Awekotuku and Allison Morris for inadvertently inspiring a young Maori woman coming into a political consciousness; Biko Agozino for uplifting use of awesome intellect; and, last but not least, Maia Orana whose infrequent eruptions in the middle of the night called to mind an Ethiopian proverb about resilience in the face of adversity: 'When the great lord passes, the wise peasant bows deeply and farts silently.' If ever a slogan were needed to inspire ethnic minorities to forge new images using their own media, this would be our pick. 